\title{
RUSINI GALICYJSCY DRUGIEJ POŁOWY XIX - POCZACTKU XX WIEKU MIĘDZY UKRAIŃSKIM A WSZECHRUSKIM WARIANTEM TOŻSAMOŚCI NARODOWEJ
}

\section{Ołena Arkusza}

Instytut Ukrainoznawstwa im. I. Krypiakewycza NAN Ukrainy we Lwowie

\author{
ABSTRACT \\ GALICIAN RUSYNS IN THE SECOND HALF OF THE $19^{\text {TH }}$ AND THE \\ EARLY $20^{\text {TH }}$ CENTURY BETWEEN UKRAINIAN AND PAN-RUSSIAN \\ PROJECTS OF NATIONAL IDENTITY
}

The formation of modern Ukrainian national identity in Galicia in the $19^{\text {th }}$ - the early $20^{\text {th }}$ century was a long and difficult process, not devoid of alternatives. The starting point was the delimitation of the cultural and spiritual space of the Commonwealth, declaring that the Galician Ukrainians are entitled to independent national development separate from the Poles. Although among the Galician Ukrainians there were supporters of a two-stage national identity - "gente Rutheni, natione Poloni" - the Ukrainian-Polish relations in Galicia developed by the logic of a struggle between nations. After separating from the Poles, the ideologues of the national movement of Galician Rusyns faced the task of defining "their" territory and history, of forming literary language. They expected serious difficulties on this way. The conservative attachment to "old Rus," backed by a large role of the Greek Catholic clergy, has created a database for searches of national identity within a wide pan-Russian space. However, the Russophile orientation was only a step to the establishment of modern Ukrainian identity, and an attempt of some of its ideologues to equate pan-Russian space with Russian space led to its split and fall in popularity. Much more attractive to Galician Ukrainians was the "Ukrainian project" built by means of the new "Shevchenkivska" culture from Dnieper Ukraine. With the turn of the $19^{\text {th }}$ and $20^{\text {th }}$ century the idea of an independent Ukrainian democratic state, which had to overcome all contradictions, began to function as a kind of perfect recipe for happiness. It captured more and broader sectors of the population, although it seemed achievable at a remote time in the future.

Key words: Galicia, national identity, Ukrainians, Russophiles.

Słowa klucze: Galicja, tożsamość narodowa, Ukraińcy, rusofile. 
Długi wiek XIX w historiografii ukraińskiej jest znany jako okres „odrodzenia narodowego". Dzieje Ukrainy wręcz utożsamiane są z rozwojem ukraińskiego ruchu narodowego. Uważa się przy tym, że ukraiński ruch narodowy rozwijał się według schematu typowego dla większości narodów Europy Środkowo-Wschodniej pozbawionych własnego państwa oraz elit społecznych. Według Miroslava Hrocha ten schemat obejmuje trzy etapy: 1) zbierania spuścizny kulturowej, kształtowania języka literackiego na podstawie ludowego oraz formowania idei narodowej; 2) organizacji ,infrastruktury” ruchu narodowego; 3) tworzenia partii politycznych oraz podejmowania działań zmierzających do suwerenności. Definicja „odrodzenia narodowego" (pochodząca z włoskiego risorgimento) nie jest do końca doskonała, ponieważ opiera się na założeniu, że nacja istnieje od czasów dawnych i tylko przez niekorzystne warunki polityczne znalazła się w stanie ,upadku”.

Historycy dyskutują, czy możemy mówić o „odrodzeniu” czy raczej o „narodzeniu" nowoczesnej nacji ukraińskiej w XIX wieku. Prymordialiści (z łac. primordium - zawiązek, wczesna faza rozwoju), opierając się na pracach znanych etnicystów (brytyjskiego socjologa Anthony'ego D. Smitha oraz amerykańskiego historyka Johna Alexandra Armstronga), twierdzą, że nacje formują się na podstawie wspólnot etnicznych o pochodzeniu przednowoczesnym. W przypadku Ukraińców powoduje to uznanie bezpośredniego związku nowoczesnego ruchu narodowego Ukraińców z Rusią Kijowską. Moderniści z kolei rozwijają idee Benedicta Andersona o „wspólnotach wyobrażonych" oraz Paula Brassa o tożsamości narodowej jako zjawisku nowym w społeczeństwie, stworzonym przez elitę celem mobilizacji sił do walki z „cudzymi” elitami. Zwolennicy teorii modernistycznej uważają, że formowanie nacji rozpoczęło się dopiero w okresie nowoczesnym i w związku z transformacją społeczeństwa agrarnego w nowoczesne, kapitalistyczne. Projekt nowoczesnej nacji ukraińskiej występuje tu jako skonstruowany przez intelektualistów, którzy tylko wykorzystali materiały historyczne i językowe dla udowodnienia samoistnego bytu narodowego Ukraińców.

Chociaż dyskusje o ciągłości ukraińskiego „odrodzenia narodowego” nadal trwają, nie podlega wątpliwości, że przez cały wiek XIX znaczenie samoidentyfikacji narodowej - wśród innych tożsamości zbiorowych i indywidualnych - stale wzrastało. Wieloetniczny charakter monarchii habsburskiej uniemożliwiał realizację mocarstwowych projektów unifikacyjnych w tym państwie. W XIX wieku poszukiwania tożsamości narodowej postrzegano wśród wszystkich narodów europejskich. Wolny rozwój narodowy stał się symbolem reform liberalnych, progresu i modernizacji, mających na celu pokonanie pozostałości feudalnej organizacji społeczeństwa. Nacja była priorytetem wśród wartości społecznych, a w imię sprawy narodowej warto było cierpieć. Uświadomienie tożsamości narodowej miało pomóc człowiekowi jakby od nowa ułożyć dla siebie świat. Podczas Wiosny Ludów 1848 roku okazało się, że ambicje narodowe mają nie tylko narody tzw. historyczne, lecz także inne, a co więcej, że ideami narodowymi przejmują się szerokie warstwy społeczne. Ideologia narodowa stała się główną kategorią łączącą lub rozdzielającą ludzi.

Podstawą intelektualnych poszukiwań prowadzących do stworzenia ideologii narodowych była epoka oświecenia, kiedy to sformułowano zasadę suwerenności 
narodowej, prawa narodu do opierania się nadużyciom władzy, podważono tradycyjne wartości, otwarto przestrzeń dla demokracji i modernizacji. W dziejach narodów Europy Środkowo-Wschodniej, a zwłaszcza ukraińskiego, idee oświeceniowe przybrały konotacje narodowe, przyczyniając się do rozwoju kultury narodowej (badania historyczne i filologiczne, tworzenie prasy narodowej oraz wydawnictw książkowych, powstanie towarzystw naukowych, bibliotek, muzeów, teatrów). Nowe akcenty w procesie formowania nowoczesnych narodów przyniósł romantyzm. Przez uznanie znaczenia emocji romantycy często stawali się patriotami narodowymi. Uważając naród z jego charakterem narodowym i narodową kulturą za wielką wartość, propagowali zainteresowanie folklorem, etnografią, poszukiwali bohaterów w historii. Ówczesna inteligencja ukraińska pozostawała pod dużym wrażeniem twórczości filozofa niemieckiego Johanna Gottfrieda Herdera, przewidującego wielką przyszłość dla narodów słowiańskich i uważającego Ukrainę za „nową Grecję”. Romantyzm dobrze przyjął się na Ukrainie, ponieważ kozaczyzna okazała się idealną inspiracją dla twórców tego czasu'.

Tymczasem obszar Galicji Wschodniej w okresie kształtowania się nowoczesnych tożsamości narodowych był częścią monarchii habsburskiej. Dla mieszkańców tego kraju znalezienie się pod panowaniem austriackim było doświadczeniem nowym i nieco niezwykłym. Między polskim panem a ukraińskim chłopem pojawił się bowiem urzędnik austriacki, którego zamiarem było przede wszystkim dołączenie obszaru nowo nabytego dla monarchii do cywilizacji europejskiej. Przestrzeń tę uważał za całkiem nieuporządkowaną, niezagospodarowaną, później jednak sam ulegał wchłonięciu przez nią. Od tego momentu kultura polska utraciła rolę głównego pośrednika między ludnością ukraińską a Europą Zachodnią, skąd zazwyczaj napływały idee modernizacyjne. Przedstawiciele różnych narodów - stając naprzeciw siebie w Wiedniu, w wojsku, w uzdrowiskach, dowiadując się o sobie, czytając czasopisma - wytwarzali oryginalną przestrzeń polityczną: kontrowersyjną, mozaikową, a jednak zmuszającą do koegzystencji, w ramach której każdy miał nauczyć się szanować innych, liczyć się z ich zdaniem, szukać kompromisów. Właśnie w kontekście innych nacji i przy świadomości swojej odmienności rodziła się tożsamość narodowa.

Tożsamość narodowa Rusinów w Galicji nie od razu ukształtowała się w jednym wyznaczonym kierunku. Było to raczej dość skomplikowane oddziaływanie wzajemne różnych wyobrażeń o przeszłości i przyszłości narodu. W poszukiwaniach oraz konstruowaniu nowoczesnej tożsamości narodowej intelektualiści ukraińscy w Galicji rozmawiali przede wszystkim z Polakami. Mieszkając razem i funkcjonując w ramach autonomii galicyjskiej, Ukraińcy i Polacy mieli szansę opracować strategie stosunków międzynarodowościowych, licząc się z większymi projektami narodowymi. Korzystne warunki dla działalności politycznej w Galicji zwracały uwagę licznych

1 Dokładniej o ukraińskim „odrodzeniu narodowym” w XIX w. w syntezach z historii Ukrainy: O. Subtelny, Ukraine. A History, Toronto 1988; P.R. Magocsi, A History of Ukraine, Toronto 1996, В. Сарбей, Наиіональне відродження України, Київ 1999; Я. Грицак, Нарис історії України: формування модерної української нації XIX-XX cm., Київ 2000; О. Аркуша, К. Кондратюк, М. Мудрий, О. Сухий, Час народів. Історія Украйни XIX століття. Навч. посібн., ред. М. Мудрий, Львів 2016. 
działaczy z innych prowincji habsburskiego imperium. Skutkowało to z jednej strony pojawianiem się w kraju nowatorskich pomysłów i napływem różnych wybitnych osobowości, z drugiej jednak zmuszało społeczeństwo - niepozbawione wewnętrznych sprzeczności - do reagowania na wyzwania zewnętrzne i podporządkowywania im swoich nierozwiązanych kwestii.

\section{SPOŁECZNOŚĆ GALICJI}

W momencie przyłączenia do monarchii habsburskiej obszar Galicji pozostawał tradycyjnym, rolniczym krajem. Ludność ukraińska (według ówczesnej terminologii - ruska) w absolutnej większości była chłopska. Wyższe warstwy społeczności - szlachta i ziemiaństwo zarówno polskiego, jak i ruskiego pochodzenia - zupełnie przyjęły polskość, w sensie politycznym uważając siebie za część polskiego narodu. Tylko niektórzy przypominali o swoim ruskim (etnicznym lub terytorialnym) pochodzeniu. Z kolei Habsburgowie dokładali starań, by zrobić chłopa nie poddanym pana, lecz poddanym państwa. W środowisku włościańskim szerzyły się wyobrażenia o „dobrym cesarzu” - o Wiedniu jako obrońcy włościan przed „polskimi panami”. Dodatkowo w Galicji Wschodniej konflikty społeczne między panem a chłopem miały konotacje narodowościowe. Chłopi ruscy pozostawali obojętni wobec prób włączenia ich do powstań polskich, ironicznie traktowali hasło „Za wolność naszą i waszą". Ideolodzy ruchów narodowych kierowali swe programy w większości ku włościanom, uważając, że to oni przechowują „czystego ducha narodowego”, są źródłem mobilizacji sił narodowych. Wieś stała się zatem polem bitwy między ideologami różnych projektów narodowych. Trudno dzisiaj o rzetelną charakterystykę stanu świadomości zbiorowej chłopów galicyjskich XIX wieku, ponieważ zachowane źródła często ukazują w rzeczywistości nie chłopów, lecz przemawiającą w ich imieniu inteligencję.

Wyższą warstwą, a zarazem narodową inteligencją społeczności ruskiej w Galicji przez niemal cały wiek XIX było duchowieństwo greckokatolickie. W pierwszej połowie XIX wieku odseparowało się od niegdyś wspólnej z włościanami „kultury wiejskiej”, zbliżając się - gdy spojrzymy z perspektywy stylu i poziomu życia - do warstwy średniej ${ }^{2}$. Po reformach terezjańsko-józefińskich z końca XVIII wieku sytuacja duchowieństwa greckokatolickiego paradoksalnie się poprawiła: zostało ono zrównane $\mathrm{w}$ prawach $\mathrm{z}$ łacińskim. Polepszenie sytuacji materialnej oraz poziomu wykształcenia greckokatolickich księży, a także nałożenie na nich niektórych obowiązków zarezerwowanych dotychczas dla urzędników państwowych podnosiło rangę osoby księdza w gminie. Proces ten skutkował tym, że duchowni greckokatoliccy z czasem zaczęli pełnić rolę przywódców narodowych. Według określenia Johna-Paula Himki duchowieństwo służące narodowi stało się największym nabytkiem dla

2 А. Заярнюк, Ідіоми емансипації. „Визвольні” проєкти і галищьке село в середині XIX століття, Київ 2007, s. 106. 
Ukraińców w dobie oświeconego absolutyzmu³. Galicyjski metropolita greckokatolicki w Soborze św. Jura we Lwowie długo był traktowany przez władze państwowe niemal jako oficjalny reprezentant galicyjskich Rusinów.

W środowisku księży greckokatolickich formowały się orientacje narodowo-polityczne galicyjskich Rusinów, w domach księży dyskutowano o sprawach politycznych, ich rodziny były podstawowym środowiskiem kształtowania się inteligencji duchownej, a nieco później także i świeckiej. Były połączone między sobą licznymi koligacjami, tworzyły rody księżowskie nawet o kilkuwiekowej historii. Właśnie dzięki tym genealogicznym koneksjom - przez przekazywanie tradycji, języka i kultury, a także dzięki przywiązaniu do odrębności obrządku - zachowało się poczucie przynależności do „starej Rusi”. Tak ważna rola duchowieństwa stwarzała także problemy dla ruchu narodowego Rusinów galicyjskich, bowiem był to ruch konserwatywny i nastawiony lojalistycznie wobec władz austriackich. Idee „starej Rusi” pielęgnowały ponadto środowiska sprzyjające Rosji - rusofile 4 .

Dopiero w ostatniej ćwierci XIX wieku młodzież ukraińska (pochodząca przeważnie z rodzin księży greckokatolickich) zaczęła w stosunkowo większej liczbie zajmować zawody świeckie o społecznym oddziaływaniu - prawników, nauczycieli, historyków, dziennikarzy i inne. W tym czasie - głównie za pośrednictwem działalności w Radzie Państwa i Sejmie Krajowym - uformowało się pierwsze pokolenie polityków ukraińskich. Dzięki staraniom ukraińskiej inteligencji świeckiej poczucie odrębności narodowej przekształcono w program ruchu narodowego. „Służba narodowi” i propagowanie tożsamości narodowej wśród ludu stało się wówczas głównym celem działalności inteligencji. Deklarowanie odrębności narodowej Ukraińców skutkowało konfrontacją z interesami Polaków. Chociaż wśród społeczności polskiej w Galicji byli zwolennicy różnych programów politycznych, łączyło ich jednak pojmowanie Rusinów jako części polskiego narodu politycznego, traktowano ich jak „dzieci” wspólnej z Polakami ojczyzny. Uważając, że istnieje szczególne pokrewieństwo między Rusinami i Polakami, politycy polscy w Galicji utożsamiali przestrzeń narodową z polskością. W konsekwencji polska polityka zmierzała do przeciwdziałania rozwojowi narodowemu Ukraińców, zwłaszcza na polu języka i oświaty. Z tej konfrontacji Ukraińcy wychodzili z poczuciem doznanej krzywdy5. Tymczasem odseparowanie się od kulturalno-intelektualnej oraz politycznej tradycji Rzeczypospolitej Obojga Narodów, a także wykazanie swojej odrębności od polskich sąsiadów było kluczowe dla ukształtowania się nowoczesnej ukraińskiej tożsamości narodowej w Galicji.

3 І.П. Химка, Греко-католицька иерква і національне відродження у Галичині 1772-1918, „Ковчег” 1993, № 1, s. 73.

4 J.-P. Himka, Religion and Nationality in Western Ukraine. The Greek Catholic Church and the Ruthenian National Movement in Galicia, 1867-1900, Montreal-Kingston-London-Ithaca 1999; W. Osadczy, Święta Ruś. Rozwój i oddziaływanie idei prawosławia w Galicji, Lublin 2007; B. Wójtowicz-Huber, , Ojcowie narodu”. Duchowieństwo grecko-katolickie w ruchu narodowym Rusinów galicyjskich (1867-1918), Warszawa 2008; Н. Колб, „З Богом за Церкву і Вітчизну”. Греко-католицьке парафіяльне духовенство в Галичині у 90-х роках ХІХ століття, Жовква 2015.

5 J. Moklak, W walce o tożsamość Ukraińców. Zagadnienie języka wykładowego w szkołach ludowych i średnich w pracach galicyjskiego Sejmu Krajowego 1866-1892, Kraków 2004. 
Przestrzeń polityczna nie wyczerpywała wszystkich aspektów codziennego życia w wielokulturowej Galicji. Przedstawiciele różnych narodowości kontaktowali się między sobą w pracy, a także w życiu codziennym, prywatnym. W okresie modernizacji świadomości narodowej niejedna osoba zmuszona do określenia swej tożsamości nie była w stanie podać jednoznacznej odpowiedzi. I chociaż pytanie o tożsamość narodową w Galicji w XIX wieku stopniowo stawało się coraz ważniejsze, należy jednak pamiętać, że mowa tu o sferze dość płynnej, dlatego ostateczny wybór narodowości oraz sama pozycja tożsamości narodowej wobec innych tożsamości zbiorowych, do których dana osoba była przywiązana, mogły ulegać kilkukrotnym modyfikacjom, co więcej - samo rozumienie tożsamości mogło się różnić od współczesnego rozumienia tego typu pojęć.

\section{NA ROZDROŻU, CZYLI CO POKAZAŁ ROK 1848}

O intelektualnych dyskusjach w środowiskach Rusinów galicyjskich pierwszej połowy XIX wieku wiemy niewiele. Wynika to ze specyfiki bazy źródłowej - braku czasopism ukraińskich i przewagi dokumentów oficjalnych, w których zwracano uwagę głównie na działania przeciwrządowe. W korespondencji działaczy „odrodzenia narodowego" mowa jest głównie o potrzebie badań słowianoznawczych. Dopiero wydarzenia rewolucji 1848 roku podniosły na poziom dyskusji publicznej poglądy nurtujące społeczeństwo. Te zaś, ścierając się między sobą, oddziaływały na siebie wzajemnie i ulegały zmianom. Już w tym czasie w środowisku galicyjskich Rusinów widoczne są poglądy, które w późniejszym czasie posłużą za podstawę do ukształtowania się politycznych orientacji narodowopolitycznych: rusofilskiej, polonofilskiej, ukraińskiej.

Przed Wiosną Ludów jedyną świecką organizacją Rusinów galicyjskich o charakterze narodowym był Instytut Stauropigijski, powołany przez władze austriackie pod koniec XVIII wieku dzięki reorganizacji lwowskiego Bractwa Uspieńskiego. Instytut miał drukarnię, księgarnię, szkołę, był patronem cerkwi Uspieńskiej we Lwowie, prowadził badania naukowe, pretendował do roli ośrodka elity ruskiej, mającego decydować w sprawach narodowych. To dzięki badaniom członków Instytutu nakreślono dzieje Rusinów w Galicji, mające służyć za główny argument postulowanego wywalczenia w przyszłości samoistnego bytu narodowego. Konserwatywne poglądy członków Instytutu i jednoczesne pretendowanie do bycia elitą intelektualną skutkowały negowaniem propozycji oparcia ukraińskiego języka literackiego na mowie ludu, a co za tym idzie - sprzyjały idei „starej Rusi”, później zaś - rusofilstwu.

Za punkt wyjścia do formowania ukraińskiej tożsamości w Galicji przyjmuje się działalność „Ruskiej Trójcy” - kółka studentów Uniwersytetu Lwowskiego oraz Greckokatolickiego Seminarium Generalnego we Lwowie. Pod wpływem romantyzmu działacze „Ruskiej Trójcy” występowali przeciwko przyjmowaniu przez wyższe warstwy społeczeństwa ukraińskiego polskiej kultury i języka, postulowali natomiast powrót do „podstaw ludowych”, prowadząc w tym celu badania etnograficzne 
i filologiczne. Źródeł ducha narodowego poszukiwali w folklorze, uważając, że symbole, mity, obrazy - generalnie rzecz ujmując, kultura ludowa - odzwierciadlają istotę nacji. Drogę do formowania świadomości narodowej widzieli w rozwoju szeroko pojętej literatury - tekstów naukowych, literackich, historiozoficznych. Po odnalezieniu w nich „swojej” symboliki - imion, toponimów, bohaterów - człowiek miał odczuć przynależność do wspólnoty narodowej. Ten pierwszy okres „odrodzenia narodowego" nie doczekał się szybkiego i skutecznego sfinalizowania. Wprost przeciwnie, korespondencja działaczy „Ruskiej Trójcy” przed rokiem 1848 świadczy, że jej członkowie byli rozczarowani, narzekali na brak sił, nieżyczliwość władz. „Wśród wszystkich narodów słowiańskich ruski, czyli małoruski, upadł najwięcej” - te słowa Jakowa Hołowaćkiego z artykułu Stanowisko Rusinów w Galicji były najlepszym podsumowaniem działalności „Ruskiej Trójcy”. Jeszcze więcej mówią o kondycji tych działaczy ich własne losy: Markijan Szaszkewycz zmarł w wieku 31 lat, pozostając symbolem ruchu ukraińskiego, Jakiw Hołowaćkyj został rusofilem, a Iwan Wahyłewycz polonofilem i co więcej - przeszedł na protestantyzm ${ }^{6}$.

Podczas Wiosny Ludów po raz pierwszy galicyjscy Rusini podjęli próbę politycznego zorganizowania się. 2 maja 1848 roku we Lwowie dzięki wsparciu władz austriackich utworzono Hołowną Ruśką Radę. Proklamowała ona lojalność wobec rządu oraz postanawiała „wzmacniać i rozwijać naszą narodowość ruską"7. Domagała się też podziału Galicji na część wschodnią (ruską) oraz zachodnią (polską), twierdząc, że Polacy i Rusini mają odmienne cele, nie mogą się rozwijać jednocześnie w granicach jednego kraju, a ,polscy przybysze” w ostatnich wiekach pozostają dla Rusinów „nieszczęściem narodowym”. O ile potrzeba oddzielenia się od Polaków wydawała się dla nich oczywistym celem, o tyle kwestia zdefiniowania narodu (mało)ruskiego była bardziej problematyczna i działacze Hołownej Ruskiej Rady nie byli jednomyślni. Po burzliwych dyskusjach zdecydowali się wydać odezwę na zasadzie uznania jedności narodu ukraińskiego:

My, Rusini galicyjscy, należymy do wielkiego narodu ruskiego, który jednym mówi językiem i liczy 15 milionów, w tym 3,5 miliona w ziemi halickiej mieszka. Ten naród był kiedyś samodzielnym, dorównywał w sławie największym potęgom Europy, miał swój język pisemny, swoje ustawy, swoich władców.

Autorzy odezwy nadzieję na powrót Ukraińców do kręgu narodów cywilizowanych łączyli z reformami i polityką Habsburgów:

Budzą się pod tym słońcem oświecone narody dalekie i sąsiednie [...] - a my, bracia, przecież jesteśmy synami tak wielkiej rodziny ruskiej, mielibyśmy w samotności na świecie pozostać

\footnotetext{
6 М. Скринник, Наративні практики украӥнської ідентичності. Доба Романтизму, Львів 2007.

7 Головна Руська Рада. 1848-1851. Протоколи засідань і книга кореспондениії, ред. О. Турій, упоряд. У. Кришталович, І. Сварник, Львів 2002, s. 1.

8 Звернення Головної Руської Ради про поділ Галичини на дві провіниії, Львів, 17 липня 1848 p. [w:] За віру, нарід і права. Руські Ради Надсяння 1848-1850 рр., вступ та упоряд. В. Пили пов ич, Перемишль 2005, s. 57-59.
} 
i nadal w tym nieszczęśliwym zmartwieniu? [...] Bądźmy tym, kim być możemy i powinniśmy. Bądźmy narodem!?.

Ta zdecydowana wypowiedź Ukraińców na temat chęci kroczenia własną drogą w przyszłości wywołała jednocześnie podziw i opór Polaków. Bardzo kategoryczne zdanie wyraził lwowski „Dziennik Narodowy”, czasopismo odzwierciedlające poglądy konserwatywnego skrzydła Rady Narodowej, przeważnie polskich ziemian w Galicji Wschodniej. Na jego łamach stwierdzano, że Polacy i Rusini nie mogą być odrębnymi narodami i zachowując niektóre różnice, zwłaszcza w obrządku, muszą jednak dążyć ku wspólnocie, „zapominać o swej jednostce, byleby cel wyższy był osiągnięty" ${ }^{\prime 1}$. Według redakcji dzieliły Polaków i Rusinów różnice nie o narodowym, a regionalnym charakterze (,,przede wszystkim zapytujemy was, kto jest u was Rusinem? Jeżeli ci, co się od dziadów i pradziadów na ziemi ruskiej porodzili, w tym razie niemal wszyscy jesteśmy Rusinami”), stwierdzano, że język ruski w ciągu ostatnich stuleci podupadł, nie spełnia więc swoich funkcji i pozostaje dialektem języka polskiego. W „Dzienniku Narodowym” pojawia się także rozpowszechnione później w publicystyce polskiej stwierdzenie, iż dążenia Rusinów do samodzielnego bytu narodowego w rzeczywistości otwierają drogę do Rosji. W taki sposób czasopismo udowadniało, że Rusini galicyjscy są częścią polskiego narodu politycznego, a ich intencje niepodległościowe uderzają we wspólną ojczyznę:

Ludzie prawi i wykształceni, synowie jednej matki przyczyny niezgody usuwać powinni; a nie dla wszczętej raz niezgody opuszczać szeregi ojczyste, gonić za marą i szukać celu, który znaleźć niełatwym będzie zadaniem. Cała budowa wielkiego rozdwojenia, wierzajcie nam, stoi na lodzie, który acz może spóźniona wiosna życia narodowego, wśród wspólnych łez radości rozgrzeje i stopi ${ }^{11}$.

Odpowiedzią galicyjskich Rusinów na tak sformułowane sądy - uznaną przez ukraińskich historyków za dość dokładne odbicie ówczesnej wyobraźni Rusinów na temat ich własnej tożsamości narodowej - był opublikowany w roku 1848 tekst zatytułowany Słowo przestrogi, autorstwa greckokatolickiego księdza Wasyla Podołynśkiego. Porównał on spory polsko-ruskie do kłótni „dwóch braci”, przez którą „,serce boli wszystkich Polaków, wszystkich Rusinów", chociaż z początkiem życia konstytucyjnego należy udowadniać, że my „wolności godni”. Autor uznawał, że losy dziejowe Rusinów i Polaków w ciągu ostatnich wieków były splecione tak mocno, iż nie można widzieć przyszłości, nie uwzględniając tych związków. Niemniej jednak obraz odrodzonej Polski miał w oczach Podołynśkiego wyglądać nie mniej mglisto niż samoistny byt narodowy Rusinów. Proponował, aby się liczyć z wrażliwością uczuć narodowościowych oraz aby się zwracać do ludu ruskiego, uznając, że są oni Rusinami, bo tylko w ten sposób można zdobyć jego życzliwą postawę. Natomiast urażając uczucia narodowe Rusinów, lekceważąc ich dzieje, język i plany na przyszłość, Polacy - zdaniem Podołynśkiego - z własnej winy oddalali ich od siebie.

9 Оттозва до руского народу, „Зоря Галицка” 1848, № 1 (15 V).

10 „Dziennik Narodowy” 1848, nr 2 (25 III).

11 J. Supiński, [Bez tytutu], „Dziennik Narodowy” 1848, nr 39 (9 V). 
Ważną częścią pracy Podołynśkiego są jego rozważania na temat tego, w jaki sposób galicyjscy Rusini odczuwali i wyrażali własną tożsamość. Według niego, „tęsknota”, którą uważał za cechę charakteru narodowego Rusinów, odróżniającą ich od innych narodów, tak naprawdę jest „tęsknotą” za samym sobą, „,za wolnością i narodowością, tj. za Rusią", od których to wartości ludność ruska w ostatnich wiekach odeszła z racji wynarodowienia. A jednak, mówiąc po polsku, nie posiadając własnego ziemiaństwa, i tak nadal - jak pisał:

[...] jesteśmy Rusinami i wierzymy mocno w zmartwychwstanie Rusi wolnej, niepodległej, prędzej czy później. [...] Kocham Polskę jako siostrę rodzoną, ale więcej kocham Słowiańszczyznę, bo jako matkę, a najczulej kocham Ruś, bo w niej kocham sam siebie. Oto jest zeznanie wiary mojej, a ręczę wam, że i omal nie wszystkich, wolno, jako i niewolniczo myślących, Rusinów.

Podołynśkyj wyodrębnił kilka wariantów tożsamości wśród galicyjskich Rusinów:

I. Partia czysto ruska - chce Rusi wolnej, niepodległej, a zmierza do niej wprost, bez ogródki, lub przez Słowiańszczyznę.

II. Partia polsko-ruska - chce Rusi wolnej, niepodległej, a zmierza do niej za pośrednictwem Polski federacyjnej [...].

III. Partia austriacko-ruska - chce Rusi wolnej tylko od Polaków, a niekoniecznie od niewoli $[\ldots]$.

IV. Partia rosyjsko-ruska - chce także Rusi, może i wolnej, a zmierza do niej za poprzednim złączeniem się z Rosją.

Swoją pracę zaś podsumowywat:

[...] każdy Rusin sam dla siebie z nieśmiałością jeszcze duma o swojej Rusi, bo nie może jeszcze znaleźć punktu mocnego a rzetelnego, na którym by swoją Ruś oprzeć mógł².

Odezwa Hołownej Ruśkiej Rady, przewidująca zjednoczenie galicyjskich Rusinów zgodnie z ukraińską/małoruską tożsamością, nie położyła kresu niepewności, lecz zapoczątkowała dość długi okres starć o charakterze czysto teoretycznym. Orientacje narodowo-polityczne Rusinów nie były wówczas zdefiniowane, pojawiały się coraz to nowsze argumenty za lub przeciw jednym czy drugim, w końcu zmieniali się sojusznicy mający dopomóc w ich wcieleniu w czyn. Słusznie porównano ówczesne poszukiwania Rusinów z „lotem Ikara we wszystkich kierunkach” ${ }^{13}$. W ciągu życia niejeden galicyjski Rusin zdążył być polonofilem, ukrainofilem, rusofilem i prawie zawsze - austrofilem, nie zaprzeczając przy tym swojej „ruskości”, chociaż w różny sposób oceniając jej perspektywy. Bieg wypadków pokazał, że deklaracja Hołownej Ruśkiej Rady bynajmniej nie była wynikiem przekonania galicyjskich Rusinów o tym, że należą do nacji ukraińskiej; raczej świadczyła, iż odczuwają oni odrębność od Polaków i przyciąganie do małoruskiej przestrzeni kulturowej. Po upadku rewolucji 1848 roku i wygaśnięciu nadziei Rusinów na rozszerzenie praw narodowych wzrosły nastroje rusofilskie.

12 В. Podoliński, Słowo przestrogi [1848], вид. Ф. Стеблій, „Записки Наукового товариства імені Шевченка” (Львів) 1994, т. 228: Праиі Історично-філософської секиії, s. 444-462.

13 J.-P. Himka, The Construction of Nationality in Galician Rus'. Icarian Flights in Almost All Directions [w:] Intellectuals and the Articulation of the Nation, eds. R.G. Suny, M.D. Kennedy, Ann Arbor (Mich.) 1999, s. 109-164. 


\section{STARORUSINI, RUSOFILE, MOSKALOFILE}

Problem rusofilskiego (moskalofilskiego) ruchu w Galicji wciąż pozostaje zagadnieniem dyskusyjnym w historiografii, chociaż napisano na ten temat wiele gruntownych prac ${ }^{14}$. Można zgodzić się z wnioskiem Anny Veroniki Wendland, że dyskusje terminologiczne i próby konceptualizacji etapów ruchu rusofilskiego wyglądają niepewnie, ponieważ

[...] próbują ściśle rozgraniczyć różne kierunki, które w praktyce nigdy nie istniały w czystej postaci, tak jak odcienie między różnymi formami ukrainofilstwa i rusofilstwa były różnorodne, przejścia między nimi niewyraźne, tożsamości jeszcze nie dość jednoznaczne, a potwierdzają to wyniki badań nad działalnością rusofilów na prowincji oraz życiorysy rusofilskich działaczy ${ }^{15}$.

Przykładowy galicyjski rusofil w XIX wieku był działaczem społecznym i oświatowym, oddanym tradycjom obrządkowym i kulturowym „starej Rusi”, zwłaszcza w języku i pisowni, ponadto był lojalny wobec władz i miał dość niewyraźne wyobrażenie, czym ta Ruś była, jest i jaka w przyszłości będzie. Taki typ rusofila ukraiński polityk z przełomu XIX i XX wieku, Teofil Okunewśkyj, ocenił następująco:

Moskalofile nasi w rodzaju Kułaczkowśkiego lub Dobrianśkiego nie mają odwagi powiedzieć, czy są Moskalami czy Moskalami nie są, a tylko tak, żeby odłożyć sprawę ${ }^{16}$.

Ideowych źródeł koncepcji panruskich w Galicji należy szukać w rozważaniach intelektualnych prowadzonych na fali „odrodzenia” narodów słowiańskich. Słowianofilstwo jako przeciwstawienie się światu germańskiemu było pierwszym przejawem dla sformułowania idei narodowej, kompensując przy tym poczucie młodszości cywilizacyjnej ${ }^{17}$. Niewątpliwie punktem wyjścia orientacji rusofilskiej w Galicji było pragnienie tamtejszych działaczy ruskich, aby oddzielić się od Polaków, przeciwstawiając im liczniejszą wspólnotę narodową. Jedną z takich możliwości stanowiło utożsamienie siebie z przestrzenią panruską, wywodzącą swój rodowód od Rusi Kijowskiej. O wspólnej tradycji dziejowej z Rosjanami świadczyły badania naukowe, a na kulturową bliskość wskazywało podobieństwo etnonimów руськi/русские, wykorzystanie cyrylicy, przekonanie - a raczej złudzenie - co do podobieństwa

14 А.В. Вендланд, Русофіли Галичини. Украӥнські консерватори між Австрією та Росією, 1848-1915, Львів 2015; W. Osadczy, Święta Ruś. Rozwój i oddziaływanie idei prawosławia w Galicji, Lublin 2007; О. Сухий, Від русофільства до москвофільства (російський чинник у громадській думиі та суспільно-політичному житті галищьких украйнців у ХІХ столітті), Львів 2003; О. Аркуша, М. Мудрий, Русофільство в Галичині в середині XIX - на початку XX ст. Генеза, етапи розвитку, світогляд, „Вісник Львівського університету. Серія історична” 1999, вип. 34, s. 231-268.

15 А.В. Вендланд, op. cit., s. 620.

16 Переписка Михайла Драгоманова з Теофілем Окуневським (1883, 1885-1891, 1893-1895), Львів 1905, s. 224.

17 J. Chlebow czyk, O prawie do bytu małych i młodych narodów. Kwestia narodowościowa i procesy narodotwórcze we wschodniej Europie środkowej w dobie kapitalizmu (od schytku XVIII do początków XX w.), Warszawa-Kraków 1983, s. 302. 
języków ${ }^{18}$. Jeszcze większe znaczenie miało udowodnienie wspólnej historii. Historycy ruscy (Denys Zubryćkyj, Antonij Petruszewycz, Izydor Szaranewycz, Fedir Swystun i inni ${ }^{19}$ ) bronili prawa „Małej Rusi” do kontynuowania kulturowej i politycznej tradycji, która w tym czasie była już monopolizowana przez Rosję. Z kolei historycy rosyjscy, tworząc podstawy ideowe imperium, twierdzili, że centrum dawnej Rusi przeniesiono z Kijowa do Rosji, a spuścizna Rusi Kijowskiej stała się podstawą Imperium Rosyjskiego. Atrakcyjne dla intelektualistów galicyjskich okazało się też to, że Rosja była wówczas jedynym samodzielnym dużym państwem słowiańskim.

Rząd i kręgi polityczne w Rosji próbowały popierać rusofilów w Galicji, uważając że słowianofilstwo jest w stanie zdobyć się na stanie się przeciwwagą dla zachodnioeuropejskiej modernizacji ${ }^{20}$. Podstawą słowianofilstwa rosyjskiego był wyidealizowany obraz jedynego narodu panruskiego zamieszkującego obszar od Karpat aż do Kamczatki ${ }^{21}$. W pierwszej kolejności chodziło o ukształtowanie się nowoczesnej świadomości narodowej Rosjan, a bez Małorusinów istniało duże ryzyko dla utrzymania europejskiej oraz mocarstwowej potęgi państwa rosyjskiego. Ideolodzy rosyjskiego nacjonalizmu proponowali oprzeć ideę narodową na koncepcie „ogólnoruskości” (общерусскость), łączącym w jeden wyobrażony obszar geograficzny „swojej przestrzeni” - „odwieczne ziemie ruskie” (исконно русские земли), w tym Ruś Halicką, Bukowinę i Zakarpacie. W roku 1902 w Petersburgu powołano Galicyjsko-Russkie Towarzystwo Dobroczynne, mające działać na rzecz utrzymania jedności „ruskich” (русских) w Galicji, na Bukowinie, na Zakarpaciu i w Rosji22. W praktyce jednak było ważnym ośrodkiem koordynującym ingerencje Rosji w sprawy galicyjskie. Rosjanie uważali wspieranie kierunku prorosyjskiego w Galicji za obronę „siebie samych":

[...] ratujemy tylko to, co było naszym, co jest i będzie naszym; i nikt nie ma prawa do tego mieszać się $e^{23}$.

Zainteresowanie ze strony Rosjan było inspiracją dla ambicji galicyjskich Rusinów, a jednak przestrzeń wszechruską wyobrażali sobie oni w dalszym ciągu dość niewyraźnie. Podróże i kontakty były nieliczne, a zdobyte podczas nich doświadczenia nie zawsze coś wyjaśniały. Z kolei formowanie nowoczesnych nacji w przestrzeni wszechruskiej, przewidujące uświadomienie sobie niedających się połączyć różnych

18 Б. Дідицкій, В одинъ часъ научиться малорусину по велико-русски, Львів 1866, s. 3.

19 І. Куци й, Украӥнська науково-історична думка Галичини (1830-1894). Рецепиія національної історії, Тернопіль 2006.

20 А. Поповкин, Славянские благотворительные общества в Москве и Санкт-Петербурге (1858-1921 г2.), диссертация канд. ист. наук, Воронеж 2013.

21 А. Бахтурина, Политика Российской империи в Восточной Галиции в годы Первой мировой войны, Москва 2000, s. 7.

22 Уставъ Галиико-рускаго благотворительнаго общества въ С.-Петербургь, С.-Петербургъ 1913, s. 3.

23 И. Гумецкий, Значеніе русскаго Прикарпатья для Россіи. Прикарпатье, будущее - второе Приамурье для Россіи въ предстоящей ей борбъ съ вьроломною Западною Европою, С.-Петербургъ 1904, s. 21. 
tożsamości, odbywało się powoli. Ukraińcy w Imperium Rosyjskim bez żadnego konfliktu wewnętrznego w większości godzili w sobie dwie tożsamości narodowościowe, w tym oficjalną rosyjską (общерусская). Inteligenci ukraińscy w Rosji często czuli się poddanymi cara rosyjskiego, reprezentantami kultury rosyjskiej oraz nośnikami patriotyzmu małoruskiego. Widoczna rusyfikacja Ukrainy nad Dnieprem wzmacniała sceptyczne usposobienie wobec perspektywy ukraińskiej nawet wśród znanych polityków galicyjskich.

Starałem się przekonać siebie - wspominał Jewhen Ołesnyćkyj podróż do Kijowa w połowie lat 90. XIX wieku - że ta moskiewszczyzna to tylko powierzchowna osłona, pod którą żyje treść ukraińska i wyjdzie wcześniej lub później na górę. A jednak to było sprzeczne z rzeczywistością, a z napisu na pomniku Chmielnickiego niczym gorzka ironia świeciła: jedyna, niepodzielna Rosja. Nie znalazłem wtedy w Kijowie tego, czego szukałem i czego spodziewałem się znaleźćc ${ }^{24}$.

Rzeczywiście Rusini galicyjscy patrzyli przede wszystkim na Kijów. Wskazuje na to chociażby artykuł Poglad w przyszłość (Поглядъ въ будучность), prawdopodobnie autorstwa Iwana Naumowycza, który traktuje się jako manifest rusofilów. Najczęściej cytowane są dwa jego fragmenty: „Ruś Halicka, Węgierska, Kijowska, Moskiewska, Tobolska i in. pod względem etnograficznym, historycznym, leksycznym, literackim, obrządkowym - to jest jedna i taż sama Ruś” oraz „Nie jesteśmy Ruthenami z roku 1848, jesteśmy prawdziwymi Rosjanami (русскіu)”. Wnioskuje się na podstawie tych ustępów o utożsamieniu Ukraińców i Rosjan, a jednak autor stwierdzał, że ,granica nasza narodowa - to nie jest Dniestr, tylko dalej od Dniepra”25. To znaczy, że właśnie Dniepr i Ukraina Naddnieprzańska były znacznikami dla określenia „swojego" terytorium etnicznego. Autor miał na celu włączenie Rusinów galicyjskich do szerszej przestrzeni narodowej, której nie utożsamiał jednak z rosyjską; wywodził jej granice poza obszar Galicji, co było dość typowym przykładem ekspansywności w początkowym etapie kształtowania się idei narodowej. Uważając Rusinów galicyjskich za część „narodu ruskiego”, rusofile pozostawali patriotami „Małej Rusi”, jednak granicę pomiędzy Małorusią a przestrzenią wszechruską każdy rozumiał na swój sposób: niektórzy byli bliscy utożsamienia Ukraińców z Rosjanami, inni na odwrót - prawie uznawali odrębność narodową jednych od drugich. Nie przesądzali tej sprawy, twierdząc, że kwestia ta ma zostać rozstrzygnięta dopiero przez historyków i językoznawców. Prasa rusofilska prawie do końca XIX wieku publikowała artykuły ukazujące różne wersje tożsamości narodowej. Według schematu: ludność halicko-ruska - szczep małoruski - naród ruski - ułożono program Russkiej Partii Ludowej (rok 1900), chociaż ideologowie ruchów narodowych już wyraźnie wymagali ścisłego określenia tożsamości narodowej ${ }^{26}$.

24 Є. Олесницький, Сторінки з мого життя, упор. М. Мудрий, Б. Савчик, авт. вступ статті О. Аркуша, Львів 2011, s. 293.

25 Одинъ именемъ многихъ [І. Наумович], Львова. Поглядъ въ будучность, „Слово” 1866, nr 59 z 27 VII (8 VIII).

26 Отзывъ [w:] Съъздъ мужей довьрія русско-народной партіи и ея организаиія, Львовъ 1900 , s. $8-9$. 
Rusofile w większości czuli się komfortowo w sytuacji „opóźnionego wyboru narodowego", w której to odpowiedź na pytanie o przynależność do nowoczesnego narodu, przewidująca spełnienie wielu warunków, okazywała się nieostateczna. Na rzecz odłożenia wyboru świadczyć miały argumenty kierujące w rzeczywistości dyskusję w stronę rzeczy drugoplanowych. „Opóźniony wybór” pozwalał rusofilom godzić dość sprzeczne postawy: ciążenie ku przestrzeni panruskiej z lojalizmem wobec Habsburgów oraz sympatie do prawosławnej Rosji z wiernością unii Cerkwi z Kościołem rzymskokatolickim. W tym sensie rusofile próbowali powtarzać zachowanie środowisk ziemiańskich, łączących patriotyzm narodowy z kosmopolitycznym trybem życia codziennego, w tym przy dworach monarchów. Domy księży greckokatolickich natomiast na mniejszą skalę powtarzały takie praktyki, przyjmując urzędników austriackich, panów polskich, oficjalistów dominikalnych. Głównym argumentem na rzecz „odłożonego wyboru” był fakt, że Rusinom w Galicji zagrażała zupełna polonizacja. $Z$ tego powodu nie mogli sobie oni pozwolić na dyskusje wewnętrzne, natomiast musieli łączyć się w obronie tożsamości, opierając się na swoim języku i tradycji. Na tym polu działacze i galicyjskie instytucje ruskie, początkowo popierające rusofilstwo czy później zostające jego sympatykami, położyły wielkie zasługi.

Rusofilskie towarzystwa polityczne i kulturalno-oświatowe - takie jak np. Ruśka Rada $^{27}$, Instytut Stauropigialny ${ }^{28}$, Narodny Dom ${ }^{29}$, Hałyćko-Ruśka Matica ${ }^{30}$, Towarzystwo im. M. Kaczkowskiego ${ }^{31}$ - prowadziły badania historyczne i filologiczne, popierały oświatę, wydawały czasopisma, prace naukowe i książki dla ludu, urządzały czytelnie itp. Wszystko to tworzyło podstawę samodzielnego bytu narodowego. Wiele dokonań rusofilów wcale nie było zorientowanych na Rosję, natomiast towarzyszył im zupełnie inny kontekst kulturowy. Dla przykładu, austriacki slawista Michael Mozer jest przeciwnikiem uproszczonego traktowania stosowanej przez rusofilów znanej mieszanki językowej - tzw. ,jazyczija” (язичія). W kontekście traktowania rusofilów jako błędnej linii rozwoju narodu ukraińskiego uważa się, że był to język zupełnie sztuczny. Mozer natomiast akcentuje, że praktyki językowo-literackie w tym czasie były dość skomplikowane i włączały różnorodne segmenty rozwoju ${ }^{32}$. W taki sposób badając różne aspekty rusofilskiego ruchu w Galicji, historycy wnioskują, że nie ma sensu traktowanie tego ruchu jako zjawiska ,zdrady” w stosunku do

27 В. Кудлач-Мельник, Політичне товариство „Руська Рада” (1870-1914 рр.), автореф. дис. канд. іст. наук, Івано-Франківськ 2008.

28 І. Орлевич, Ставропігійський інститут у Львові (кінець XVIII - 60-pp. XIX cm.), Львів 2001; О. Ки и чук, Львівський Ставропігійський інститут у громадському жсттті Галичини другої половини XIX- початку XX ст., Львів 2001.

29 Г. Сіромська, Народний Дім у Львові. Від старорусинства до русофільства (середина $X I X-$ початок $X X$ cm.), Львів 2014.

30 О. Се для р, „Галицько-руська матиия”. Завдання, організація, члени товариства, „Україна. Культурна спадщина, національна свідомість, державність” 2012, т. 21, s. 668-692.

31 P.R. Magocsi, The Kachkovs'kyi Society and the National Revival in Nineteenth-Century East Galicia, „Harvard Ukrainian Studies” (Cambridge, Mass.) 1991, vol. 15, no. 1-2, s. 48-85.

32 М. Мозер, „Язичіє”- - ссевдотермін в українському мовознавстві [w:] idem, Причинки до історії української мови, ред. С. Вакулен ко, Вінниця 2011, s. 641-666. 
narodu ukraińskiego i że takie ujęcie wywodzi się z polemiki publicystycznej swego czasu oraz było obecne w historiografii sowieckiej i postsowieckiej.

Nowe akcenty w ruchu rusofilskim w Galicji widoczne były od początku XX wie$\mathrm{ku}$. Wewnątrz ruchu pojawiła się grupa młodszych działaczy zorientowanych na Rosję, która ostro zaatakowała konserwatywne wartości „starej Rusi”. Domagali się oni otwartego uznania Rusinów galicyjskich za część narodu rosyjskiego, zrzucenia „niewolniczej maski rutheństwa" ${ }^{33}$. Jednym z czołowych ideologów moskalofilstwa galicyjskiego na początku XX wieku został publicysta, redaktor czasopisma „Ruskoje Słowo” („Руское слово”) Osip Monczałowskij. Twierdził, że projekt ukraiński nie ma siły życiowej i udowadniał niemożliwość oddzielenia Małorusinów od Rosjan ${ }^{34}$. Sprzeczności ideowe w latach 1908-1909 spowodowały rozłam ruchu rusofilskiego na starorusinów (Mychajło Korol) oraz moskalofilów (Wołodymyr Dudykewycz/ Władimir Dudikiewicz, Dmytro Markow/Dmitrij Markow). Moskalofile napastliwie walczyli przeciwko programowi ukraińskiemu, twierdząc, że:

[...] różnice między nami wzrastają nawet nie co roku, a codziennie i co godziny, że mamy przed sobą ludzi, którzy różnią się od nas nazwą, językiem, zachowaniem, charakterem, dążeniami, kulturą - i nawet - co jest najważniejsze - pojęciem moralności. Odeszliśmy wzajemnie na taką odległość, że poczuwamy się w ich towarzystwie bardziej cudzymi niż w towarzystwie byle jakich cudzoziemców ${ }^{35}$.

Dążąc do zaostrzenia programu antyukraińskiego, moskalofile próbowali znaleźć sojuszników wśród niektórych polityków polskich, ci zaś uważali, że popieranie różnych prądów w ruchu ukraińskim ma jakiś sens, bowiem w ten sposób osłabia się ów ruch w całości. Poparcie udzielone rusofilom odpowiadało też interesom polskiej demokracji narodowej, zorientowanej na Rosję. Porozumienie z politykami polskimi nie było dla rusofilów proste, przecież dotychczas tworzyli oni swoją ideologię, wykorzystując hasło walki z Polakami jako reprezentantami wrogiej wobec „ducha ruskiego" kultury zachodniej. Sojusze taktyczne rusofilów z polskimi politykami zaowocowały dla nich straceniem popularności politycznej wśród społeczności ukraińskiej. Chociaż moskalofile głośno artykułowali swoją obecność, nie współdziałali oni lokalnie, przyznawała to nawet strona rosyjska. Dowódców rusofilskiego ruchu w Galicji czekały trudne czasy w okresie Wielkiej Wojny, austriackie obozy koncentracyjne i nawet, co może wydawać się paradoksalne, represje od strony nowej, sowieckiej władzy Rosji.

33 Первое общерусское слово въ австрійскомъ парламенть, „Галичанинъ” 1907, № 143 z 28 VI (11 VII).

34 О. Мончаловскій, Святая Русь, Львів 1903.

35 Печальное явленіе, „Галичанинъ” 1907, № 216 z 9 Х. 


\section{OD RUSINÓW DO UKRAIŃCÓW. KSZTAŁTOWANIE SIĘ NOWOCZESNEJ TOŻSAMOŚCI UKRAIŃSKIEJ W GALICJI}

Ważną przesłanką dla kształtowania się nowoczesnej tożsamości narodowej w Galicji były reformy państwowe z lat 60 . XIX wieku. Dzięki nim wytworzyła się przestrzeń do dyskusji oraz możliwość organizacji narodowych instytucji. Demokratyzacja spowodowała podniesienie uczuć narodowych, a nawet pewną modę na ich ujawnianie. Anatol Wachnianyn wspominał, że:

Ruś Galicyjska była wtedy jednolita. Nie widzieliśmy jeszcze żadnych partii ani kółek. Wszędzie odczuwało się szczerość oraz miłość do swego ${ }^{36}$.

Na początku lat 60. XIX wieku działacze ruscy dbali o zademonstrowanie swojej odrębności od Polaków, wytworzenie własnej przestrzeni politycznej i kulturalno-intelektualnej. Mało dyskutowano między sobą o całokształcie tożsamości narodowej, a w przestrzeni publicznej dominujące było twierdzenie, że należy odnowić tradycje „Ruskiej Trójcy” i Hołownej Ruśkiej Rady.

Formowanie ukraińskiej - zbliżonej do współczesnej - świadomości narodowej w Galicji powiązane było z ruchem narodowym. W odróżnieniu od swoich poprzedników, mówiących jedynie o przynależności do piętnastomilionowego narodu małoruskiego na podstawie wspólnego języka ludowego oraz bliskości etnicznej, narodowcy mogli już oprzeć się na paradygmacie narodowym - „szewczenkowskiej” kulturze Ukrainy Naddnieprzańskiej. Czytanie oraz przepisywanie poezji Tarasa Szewczenki, formowanie swoistego kultu Szewczenki w Galicji było ważnym przejawem narodowej samoidentyfikacji. Chociaż narodowcy często pochodzili z rodzin księży greckokatolickich, punktem wyjścia ich ideologii stało się uznanie, że identyfikacja narodowa ma większe znaczenie niż religijna. To otwierało drogę do pokonania ważnej przeszkody w połączeniu z Ukrainą pod władzą rosyjską - różnicy konfesyjnej. Narodowcy stwierdzali, że w ramach narodu ukraińskiego mogą współistnieć różne wyznania.

Podstawowym ośrodkiem wczesnego ruchu narodowego były hromady. Tworzono je na wzór hromad na Ukrainie Naddnieprzańskiej od początku lat 60. XIX wieku w gimnazjach i na uniwersytetach. Łączyły młodzież ukraińską, która dokształcała się w zakresie historii i kultury narodu ukraińskiego, o czym mało mówiło się w innych miejscach. Właśnie dzięki hromadom uformowała się warstwa ukraińskiej inteligencji świeckiej, która weszła w życie polityczne w ostatnich dziesięcioleciach XIX wieku i dokonała modernizacji ukraińskiego ruchu narodowego, doprowadzając do zmiany jego elit ${ }^{37}$. Według wspomnień narodowców, atmosfera w hromadach, napełniona duchem ofiarności dla sprawy narodowej, wywarła duży wpływ na ich

36 А. Вахнянин, Спомини з житя (Посмертне виданя), зладив К. Студинський, Львів 1908, s. 42.

37 С. Пахолків, Украӥнська інтелігенція у Габсбурзькій Галичині. Освічена верства і емансипація націі, Львів 2014, s. 337. 
późniejszą działalność ${ }^{38}$. Początkowo narodowców uważano za „dzieci starej Rusi”, a jednak w połowie lat 60 . XIX wieku - przede wszystkim na łamach czasopism weszli oni w polemikę z rusofilami. Narodowcy uznawali argumenty historyczne, jednak nie nadawali im znaczenia pierwszoplanowego, akcentowali natomiast przyrodzone prawo narodu do samoistnego bytu. Źródła rozwoju narodowego wiązali $\mathrm{z}$ językiem ludowym, obyczajami i kulturą. $Z$ tego powodu kategorycznie sprzeciwiali się wszelkim próbom ich „sztucznego" tworzenia, zwłaszcza wykorzystania alfabetu łacińskiego zamiast cyrylicy, formowania języka literackiego na podstawie innej niż język ludowy itd.

Narodowcy uzasadniali włączenie Galicji Wschodniej do czasoprzestrzeni ukraińskiej. Od lat 60. XIX wieku datuje się początki wykorzystywania etnonimów „Ruś-Ukraina” i „rusko-ukraiński” jako synonimicznych określeń do „Małej Rusi” czy „małoruskiego". W tworzonych przez narodowców tekstach ustalono ukraino- i kozakocentryczny model historii narodowej; Galicja Wschodnia i inne kraje ukraińskie wchodzące w skład Austro-Węgier wizualnie były przedstawiane jako część osobnej ukraińskiej przestrzeni etniczno-narodowej; szeroko wykorzystywano geografię symboliczną z utworów Szewczenki i innych pisarzy ukraińskich. W taki sposób określano „swoje” terytorium narodowe ${ }^{39}$. Narodowcy odpowiadali na pytanie, „gdzie jest ten kraj zamieszkały przez Rusinów”, za pośrednictwem pojęcia „świadomość narodowa”, dającego poczucie jedności narodowej, pomimo granic administracyjnych i państwowych. Dzieje Ukrainy traktowali jako periodyczną wymianę centrów życia narodowego między Rusią Halicką a Ukrainą Naddnieprzańską ${ }^{40}$.

Postacią bardzo ważną dla formowania ruchu narodowskiego był Wołodymyr Barwinśkyj (1850-1883), założyciel i pierwszy redaktor gazety „Diło” („Діло”), przez pół wieku pozostającej głównym organem oraz swoistym laboratorium utwierdzenia w Galicji idei Wielkiej Ukrainy. Życie i śmierć Barwinśkiego (zmarł w wieku 33 lat) było wzorem ofiarnej służby Ukrainie. Mimo problemów za zdrowiem prawie cały swój wolny czas poświęcał sprawom publicznym, głośno mówił, że należy rozróżniać postawę patriotyczną i pracę realną. Nie podobało się to zwolennikom „starej Rusi”, a jednak miał on rację. Barwinśkyj stał u podstaw ukraińskiej „pracy organicznej” w Galicji, był inicjatorem pierwszych „wieców narodowych”, które stały się formą poszerzania idei narodowej wśród ludu, komunikacji między inteligencją a włościaństwem. Pozostał uosobieniem ideału romantyka i marzyciela, który oddał życie na ołtarzu sprawy narodowej.

Szeroką paletę postaw występujących wśród społeczności galicyjskich Rusinów odbija, w części autobiograficzna, powieść Barwinśkiego pt. Kwiat skoszony. Bohater powieści Stepan, student ukraiński, nie zważając na ostrzeżenia rodziców (chociaż wychowali go na porządnego człowieka, to jednak nakazywali patrzeć na świat

38 Є. Олесницький, op. cit., s. 182.

39 О. Середа, Громади ранніх народовиів у Східній Галичині (60-і роки XIX століття), „Україна. Культурна спадщина, національна свідомість, державність” 2001, т. 9, s. 378-392.

40 М. Мудрий, Поняття „наша земля” / „наш край” в украйнському русі Галичини XIX початку ХХ століття [w:] Шляхами історії. Науковий збірник історичного факультету ЛНУ ім. I. Франка. На пошану проф. К. Кондратюка, Львів 2004, s. 172-173. 
realnie), przejął się ideałami narodowymi, marzył o sławie kozackiej, ,żeby i on jako rycerz wybrał się na koniu czarnym w step szeroki”, płakał nad Marusia Szewczenki i podziwiał „ziemię-macierz rodzimą, naszą sławną Ukrainę”. Zupełnie inny jest obraz księdza greckokatolickiego Porfyra, absolwenta seminarium wiedeńskiego. Porfyr uważa pracę narodową za zabawy młodzieńcze: ,żal mi nadziei, żal wiary, żal czasu straconego w nadziei i wierze. Realizm, realizm - oto wielkie słowo". Aspirowanie do bycia członkiem elity zaprowadziło Porfyra do koleżeństwa z ,panami i podpankami” oraz pogardy dla ludu. Natomiast chłopi zaczęli wiązać z nim wszystkie nieszczęścia, uważając, że tak naprawdę służy on nie Panu Bogu, lecz ciemnocie. W scenie finalnej Mełania, żona Porfyra, podstępem odebrana Stepanowi (jest to uosobienie tragicznego losu Rusinki, która nie pozostała przy ideałach narodowych), nie wytrzymując hańby życia z Porfyrem, popełnia samobójstwo ${ }^{41}$. Chociaż powieść była krytykowana pod względem literackim, zdobyła uznanie jako ważny manifest światopoglądowy narodowców. Wyraźnie udowodniała, że idea Ukrainy powinna być utożsamiana ze światłem, godnością, pracą dla przyszłości, natomiast jej krytycy - z konserwatyzmem i złem.

Chociaż zwolennicy „starej Rusi” próbowali nie dopuścić narodowców do udziału w życiu politycznym, traktując ich jak ,nierozumne dzieci”, które burzą spokój, to ich popularność wzrastała ${ }^{42}$. Dobrym przykładem ułożenia stosunków między zwolennikami różnych wariantów tożsamości galicyjskich Rusinów był demonstracyjny wybór przez narodowców nazwy dla czasopisma „Diło” (w sensie czynność) w przeciwieństwie do rusofilskiego „Słowa” (w sensie pustosłowie). Po utworzeniu w roku 1885 towarzystwa politycznego Narodna Rada „program ukraiński” nabył spójności. Narodna Rada stwierdzała, że kontynuuje tradycje Hołownej Ruśkiej Rady („Rusini galicyjscy są częścią wielkiego dwudziestomilionowego narodu (mało)ruskiego"43). Narodowcy proponowali uznawanie porażki Ukraińców w ramach autonomii galicyjskiej za zjawisko tymczasowe, ponieważ „naród nasz przychodzi do coraz większej świadomości narodowej”, a na polu pracy narodowej „stają nowi robotnicy”. Za główne zadanie uważano organizację sił narodu. Idei jedności narodowej nadano wręcz sakralne znaczenie. Stwierdzano, że „ruch narodowy płynie niepowstrzymanie szerokim nurtem, którego najprawdopodobniej i brama piekła nie ma siły zatrzymać", bo prawda prowadzi tutaj wojnę z nieprawdą; Ukraińcy zaś mają uświadomić sobie, że są jak ,święta rodzina”, a jedność będzie prawdziwą tarczą przed nieprzyjacielem oraz przyczyni się do „zmartwychwstania Rusi”. Takie postawienie akcentów świadczyło, że idea narodowa została umieszczona na samym szczycie wartości społecznych. Potężny naród miał być gwarancją złagodzenia konfliktu z Polakami, bowiem zatrzymaniu uległaby ofensywa silniejszego na dotychczas słabszego ${ }^{44}$.

41 [В. Барвінський] Василь Барвінок, Скомений иявіт (виїмок з галицьких образків), вступ Б. Лепкий, Київ-Ляйпціг 1910.

42 Б. Ян иш ин, Украӥнська міська політична еліта в Галичині та народовський рух останньої третини XIX cm. Становлення та інституційний розвиток, Київ 2008.

43 Загальні збори ,Народної Ради”, „Батьківщина” 1888, № 7 z (15) II.

44 Потреба організаціи, „Діло” 1885, № 118 z 25 X (6 XI). 
Przełomem dla ukraińskiego ruchu narodowego w Galicji były lata 90. XIX wieku, kiedy odbyło się ,przekształcenie ducha galicyjskiego oraz organizacji społeczno-politycznej”, a „ówczesna Ukraina Zachodnia zdefiniowała swój kształt na dłuższy czas”45. Początek tej transformacji był powiązany z tzw. „nową erą” - próbą ugody między ukraińskimi a polskimi politykami w Galicji przy współudziale rządu austriackiego. Idea „nowej ery” polegała na deklarowaniu przez Rusinów galicyjskich ukraińskiej tożsamości narodowej oraz zerwaniu z rusofilami ${ }^{46}$. Ugoda otwarła burzliwe dyskusje na temat ruchu ukraińskiego, jego sojuszników i nieprzyjaciół, „pracy organicznej”, granicy tego, co dopuszczalne w polityce, pojęcia zdrady narodowej. Problem polegał na tym, czy galicyjscy Rusini mogą nadal odsuwać pytanie o nowoczesną tożsamość narodową, dlatego że debata na ten temat wywołuje konflikty zamiast łączyć. Apel do każdego Rusina, by ściśle określił swoją tożsamość narodową, był krokiem w kierunku modernizacji politycznej, na czym zależało narodowcom. „Dzisiaj - kategorycznie stwierdziło «Dilo» na początku XX wieku nie mogą już być jacyś niewyraźni, bezbarwni Rusini”, każdy musi podjąć decyzję: „albo Ukrainiec, albo Moskal”47.

Ważnym czynnikiem utwierdzenia nowoczesnej tożsamości ukraińskiej w Galicji było też odejście lewicy politycznej od internacjonalizmu i uznanie pierwszorzędności tożsamości narodowej. Przede wszystkim stanowiło to zasługę Rusko-Ukraińskiej Partii Radykalnej (1890) ${ }^{48}$. Początkowo jej zwolennicy w Galicji, działający pod wpływem znanego federalisty Mychajła Drahomanowa, uważali, że sensem historii jest dążenie ludzkości ku swobodzie. Wyrastało stąd uznanie priorytetu wartości humanistycznych nad narodowymi. A jednak pod wpływem stosunków międzynarodowych w Galicji właśnie w tym środowisku została postawiona teza, że w konsekwencji modernizacji gospodarczej ma powstać niepodległe państwo ukraińskie. Chociaż polityczna elita narodowców już wcześniej uświadamiała sobie, że celem ruchu narodowego będzie państwo ukraińskie ${ }^{49}$, to za początek niepodległościowego ruchu w Galicji uważa się wydaną w roku 1895 we Lwowie broszurę „młodego” radykała Julijana Baczynśkiego pt. Ukraina irredenta ${ }^{50}$. Zdaniem Jarosława Hrycaka, transformacja ruskiej religijno-protonarodowej tożsamości w nowoczesną narodową rusko-ukraińską nastąpiła w wyniku pojawienia się radykalnej kultury politycznej, zbudowanej na wzorcach zachodnioeuropejskich ${ }^{51}$. Symbolem odejścia lewicy ukraińskiej od programów federacyjnych (analogiczny proces nastąpił wśród polskich

45 М. Шлемкевич, Галичанство, Нью-Йорк-Торонто 1956, s. 48.

46 D. Maciak, Próba porozumienia polsko-ukraińskiego w Galicji w latach 1888-1895, Warszawa 2006; I. Чорновол, Польсько-українська угода 1890-1894 рр., Львів 2000.

47 Маска спала, „Діло” 1900, № 26 z 3 (15) II.

48 R. Tomczyk, Galicyjska Rusko-Ukraińska Partia Radykalna w latach 1890-1914, Szczecin 2007.

49 Прибудь розум - щастя буде! Розмова Русина з Турчанського повіту з послом Константином Телішевським, Львів 1891.

50 Ю. Бачинський, Україна irredenta, передм. І. Бегей, Київ 2003.

51 Я. Грицак, Пророк у своїй вітчизні. Франко та його спільнота (1856-1886), Київ 2006, s. 435 . 
socjalistów i ludowców) stało się publiczne wystąpienie Iwana Franki, podczas którego powiedział, że czuje się przede wszystkim Rusinem i dopiero potem radykałem.

Finałem ideowej i organizacyjnej transformacji ukraińskiego ruchu narodowego w Galicji na przełomie XIX i XX stulecia było utworzenie partii politycznych. Najwięcej wpływów zdobyła stworzona na podstawie narodowców i radykałów Ukraińska Partia Narodowo-Demokratyczna - UNDP (1899). Połączenie w jej programie pojęć „nacja” i „demokracja” okazało się dla ukraińskiego ruchu prawie idealne. Działalność UNDP była zorientowana na poszerzenie ukraińskiej świadomości narodowej wśród ludu ${ }^{52}$, „pracę organiczną”, organizację miejscową, obejmującą oprócz ośrodków partyjnych instytucje kulturalno-oświatowe i gospodarcze ${ }^{53}$. Powiązane z UNDP były: Towarzystwo Naukowe im. T. Szewczenki, Proświta, Silśkyj hospodar, Dnister, Narodna Torhiwla, Sokił i inne. W taki sposób partia stała się masowym ruchem narodowym ${ }^{54}$. Dookoła UNDP łączono także inne siły polityczne, uznające ideę nowoczesnej ukraińskiej tożsamości narodowej - radykałów, socjalistów, konserwatystów. W tym czasie rusofile ustąpili miejsca narodowcom. Za odzwierciedlenie ich popularności w Galicji można uważać wyniki wyborów parlamentarnych z roku 1907, gdy rusofile zdobyli już tylko około ćwierci głosów wyborców.

Przełom w rozwoju nowoczesnej tożsamości ukraińskiej skutkował osłabieniem dyskusji o wyborze narodowym Rusinów galicyjskich, a uruchomił rozważania nad innymi istotnymi pytaniami. Wzmacnianie polityczne kontrastowało z nader skromnymi pozycjami Rusinów w autonomii galicyjskiej, wywołując w ich środowiskach rozgoryczenie. Szukając siebie w świecie, który szybko się zmieniał, młodzi ludzie ostro odczuwali dysproporcję między tym realnym a wymarzonym, własnymi ambicjami oraz karierą zawodową czy polityczną. Jedną z ich odpowiedzi na ten stan rzeczy było przygotowywanie się do zbrojnej walki o wymarzoną ojczyznę. Hasło tworzenia samodzielnego państwa ukraińskiego było utożsamiane wręcz z biletem do szczęśliwej przyszłości. Terminu jej osiągnięcia nie kalkulowano zbyt optymistycznie. Na przełomie XIX i XX wieku „Diło” proroczo stwierdziło, że będzie to za sto lat:

Wykreśleni z początkiem wieku XIX z mapy Europy, wracamy w szereg nacji i zmuszamy świat o nas mówić i przyznać nam prawo do życia... Dzisiaj jesteśmy pełni entuzjazmu oraz chęci do stałej walki, mamy nadzieję na zwycięstwo naszej sprawy, mamy wiarę, że koniec wieku XX przyniesie wskrzeszenie wolnej Rusi-Ukrainy ${ }^{55}$.

Ważnym dla wyboru przez Rusinów galicyjskich ukraińskiej tożsamości narodowej było ułożenie stosunków z Ukrainą Naddnieprzańską ${ }^{56}$. Do połowy XIX wie$\mathrm{ku}$ wzajemne zainteresowanie wynikało $\mathrm{z}$ indywidualnych twórczych i naukowych poszukiwań wąskiego kółka inteligentów, którzy chcieli pogłębić świadomość

52 В народ!, „Діло” 1902, № 101 z 7 (20) V; № 102 z 8 (21) V; № 109 z 9 (22) V.

53 Центральний державний історичний архів України, м. Львів, ф. 372: Охримович Володимир, оп. 1, спр. 14, арк. 8 (обіжник Народного комітету УНДП від 28 лютого 1903 р.).

54 В. Рас ев ич, Українська національно-демократична партія (1899-1918 рр.), автореф. канд. дис., Львів 1996, s. 11.

55 На переломі віків, „Діло” 1900, № 291 z 30 XII (12 I).

56 I. Райківський, Ідея украӥнської національної єдності в громадському житті Галичини ХІХ століття, Івано-Франківськ 2012. 
historyczną, znaleźć powiązania językowe. Kontakty między dwiema częściami Ukrainy odbywały się przez korespondencję. Działacze pierwszego okresu „odrodzenia narodowego" w Galicji uświadamiali sobie jedność narodową jako coś idealnego, wyłącznie pozytywnego. Oczekiwali od Wielkiej Ukrainy odpowiedzi na pytania i pomocy. Galicji tymczasem brakowało zasobów materialnych i intelektualnych, ażeby samodzielnie zrealizować dwa kluczowe dla ruchu narodowego zadania: standaryzację języka i ułożenie w całość dziejów narodowych. Mogli tego jednak dokonać tylko działacze narodowi z Ukrainy Naddnieprzańskiej. Rusini galicyjscy liczyli też, że Ukraina Naddnieprzańska będzie potęgą potrafiącą przeciwstawić się Polakom.

W latach 60. i 80. XIX wieku dowódcy ruchu ukraińskiego w Rosji (Pantełejmon Kulisz, Ołeksandr Konyśkyj, Wołodymyr Antonowycz, Mychajło Drahomanow) zwrócili uwagę na to, że warunki konstytucyjnej Austrii pozwalają na stworzenie w Galicji potężnego ośrodku narodowego. Ukraińcy galicyjscy również byli zainteresowani kontaktami z Ukrainą Naddnieprzańską. Rozumiejąc, że Rusini galicyjscy potrzebują intelektualnej oraz finansowej pomocy od Naddnieprzańców, ci drudzy czasem demonstrowali arogancką postawę.

Nam z Galicji nic - mówił Kulisz. - Ona nam ni sławy, ni pieniędzy, nic nie da. Jak my zrobimy, tak i będzie. Galicja, chociaż może nieco później, a jednak pójdzie za nami, jak zawsze $\operatorname{dotacd~}^{57}$.

Przywódcy ruchu ukraińskiego na Ukrainie Naddnieprzańskiej z reguły nie mieli programu działania, pozostawali częścią rosyjskiej przestrzeni politycznej, w końcu bagatelizowali stosunki polsko-ukraińskie w Galicji. Nie mogąc zdobyć wśród Naddnieprzańców należytej uwagi dla swoich problemów oraz uznania własnych wysiłków, ideologowie projektu ukraińskiego w Galicji wyrażali zwątpienie wobec jego perspektyw ${ }^{58}$. Trzeba jednak podkreślić fakt, że wygłoszony przez Naddnieprzańców pomysł przekształcenia Galicji w „ukraiński Piemont” scalił koncepcje ,pracy organicznej” oraz „walki narodowej”, podporządkując ich wyższemu celowi. Należy też mieć na uwadze, że perspektywa ogólnoukraińska nie tylko dodawała optymizmu, lecz także męczyła kraj.

Dobrym przykładem skomplikowanych stosunków między Ukraińcami z Galicji Wschodniej a tymi z Wielkiej Ukrainy mogą być losy Mychajła Hruszewśkiego już po osiedleniu się we Lwowie. Historyk ten nie stał się w Galicji „swoim”" ${ }^{9}$. W roku 1906 opublikował artykuł Galicja i Ukraina, w którym rozważał nową sytuację ruchu ogólnoukraińskiego. Wydarzenia rewolucyjne w Rosji, wykazujące słabość tamtejszych Ukraińców, rozbijały marzenia galicyjskich Rusinów o szybkiej pomocy z Wielkiej Ukrainy.

Krótko mówiąc - podsumowywał Hruszewśkyj - dotąd Galicja szła, a Ukraina stała albo szła w ślad za Galicją. Teraz Ukraina pójdzie swoją odmienną drogą i jej

57 Суt. za: Є. Нахлік, Пантелеймон Куліш. Особистість, письменник, мислитель, т. 1: Життя Пантелеймона Куліша, Київ 2007, s. 276.

58 О. Барвінський Спомини з мого життя, т. 1-2, упоряд. А. Шацька, О. Федорук, ред. Л. Винар, І. Гирич, Нью-Йорк-Київ 2004, s. 273.

59 С. Плохій, Великий переділ. Незвичайна історія Михайла Грушевського, Київ 2011, s. 51-61. 
oddalenie od Galicji będzie powiększać się z każdym krokiem, jeżeli nie zadba się o zbliżenie ich dróg. I gdyby tak każda poszła w swoją stronę, nie dbając o zbliżenie, to za jakieś 20-30 lat mielibyśmy przed sobą dwie narodowości na jednej podstawie etnograficznej, podobnie jak Serbowie i Chorwaci, dwie części jednego szczepu serbskiego, które dały się rozwieść poprzez okoliczności polityczne, kulturowe, religijne aż do pełnego wyobcowania.

Pokonać ten problem, zdaniem Hruszewśkiego, udało się w Galicji Wschodniej, ponieważ Wielka Ukraina miała dla niej znaczenie życiowe ${ }^{60}$.

Na przełomie XIX i XX wieku ruch ukraiński w Galicji wyprzedził Ukrainę Naddnieprzańską i zaczął rozwijać się według własnych reguł dyktowanych przez austriackie życie konstytucyjne. Kompleks mniejszej wartości, odczuwany w Galicji Wschodniej w początkach „odrodzenia narodowego”, przekształcił się wówczas w swoje przeciwieństwo - przekonanie wręcz o mesjanizmie Galicji Wschodniej wobec Ukrainy. Co więcej, działacze naddnieprzańscy z „,pobożną zawiścią” patrzyli na wolności polityczne swoich rodaków za Zbruczem. Na początku XX wieku ton rozmów Naddnieprzańców o Galicji zmienił się: miejsce krytyki zajęło zachwycenie życiem ukraińskim, doświadczeniem politycznym oraz planami ${ }^{61}$. Naddnieprzańcy coraz częściej czuli się w Galicji izolowani, chociaż nie chcieli się z tym pogodzić. Natomiast mieszkańcy Galicji wracali z Wielkiej Ukrainy rozczarowani i ostro krytykowali Ukraińców w Imperium Rosyjskim za zaniedbywanie sprawy narodowej, niewykorzystywanie języka ukraińskiego na co dzień. Wyimaginowany obraz Wielkiej Ukrainy od rzeczywistości dzieliła przepaść.

\section{WNIOSKI KOŃCOWE}

Formowanie nowoczesnej tożsamości narodowej wśród Rusinów galicyjskich w drugiej połowie XIX i na początku XX wieku było procesem trwałym, złożonym oraz bezpośrednio powiązanym $\mathrm{z}$ kształtowaniem się nowoczesnych tożsamości narodowych Polaków i Rosjan, a także ich próbami włączenia Rusinów galicyjskich do swoich projektów narodotwórczych. Wzajemne poszukiwanie siebie prawie zawsze miało charakter dialogu. Bardzo znaczące były w nim takie pojęcia jak: poparcie, zainteresowanie, ale również poczucie obrazy, krzywdy, lekceważenia. Dawało to dodatkowe argumenty, pobudzało do działania lub na odwrót - napełniało rozczarowaniem.

Ukraińscy ideolodzy ruchu narodowego w połowie XIX wieku uznawali, że ruch ten przegrywa w porównaniu z innymi narodami, a jednak zdecydowali się to opóźnienie wyrównać. Każde kolejne pokolenie ukraińskich działaczy narodowych marzyło o tym, żeby wykonać to zadanie w ciągu swojego życia. W rzeczywistości nie było to jednak wykonalne, zwłaszcza niewystarczające okazywało się wydanie

60 М. Грушевський, Галичина і Україна [w:] idem, Твори у 50 m., т. 1, Львів 2002, s. 380.

61 Д. Дорошенко, Мої спомини про недавнє минуле (1914-1920 рр.), Київ 2007, s. 12. 
deklaracji, napisanie artykułu czy zwołanie wiecu. Dopiero nasycenie pod koniec XIX wieku przestrzeni społecznej różnymi ośrodkami ruchu narodowego zaczęło łączyć szersze warstwy wokół idei narodowej, zmieniając stan obojętności na przywiązanie do idei samoistnego bytu narodowego oraz zaszczepiając nadzieję na rozwiązanie wszystkich problemów życiowych według Szewczenkowego: „W swojej chacie swoja i prawda, i siła, i wola".

Reasumując, należy stwierdzić, że punktami wyjścia do uformowania nowoczesnej tożsamości narodowej Ukraińców w Galicji były: proklamowanie swego prawa do samoistnego bytu narodowego, oddzielenie się od Polaków oraz niechęć do traktowania dawnej Polski jako swojej ojczyzny ideologicznej, a także utożsamiania siebie z jej kresami. Chociaż wśród Rusinów galicyjskich funkcjonowali przedstawiciele dwustopniowej tożsamości narodowej typu gente Rutheni, natione Poloni ${ }^{62}$, stosunki ukraińsko-polskie w Galicji rozwinęły się według logiki konfliktu międzynarodowego, w którym obie strony jednocześnie były dla siebie przeciwnikami, zagrożeniem oraz wzorami do naśladowania.

Po odcięciu się od Polaków przed ideologami ruchu narodowego galicyjskich Rusinów stanął problem zakreślenia „własnego” terytorium oraz spisania historii Ukrainy, a także stworzenia ukraińskiego języka literackiego. Na tej drodze napotkali jednak poważne trudności. Konserwatywne przywiązanie do „starej Rusi” z dominującą wśród ruskich elit politycznych pozycją duchowieństwa greckokatolickiego stworzyło podstawy do poszukiwania tożsamości narodowej w ramach szerokiej przestrzeni panruskiej. Z czasem okazało się, że orientacja rusofilska była tylko etapem na drodze do nowoczesnej tożsamości ukraińskiej, natomiast próby niektórych jej ideologów, by utożsamić przestrzeń panruską z rosyjską, doprowadziły do rozłamu rusofilstwa i utraty popularności.

„Projekt ukraiński”, zbudowany na podstawie nowej, „szewczenkowskiej” kultury Ukrainy Naddnieprzańskiej, okazał się dla Rusinów galicyjskich bardziej atrakcyjny. Dyskusje na temat tego, czy naród ukraiński zawsze istniał, czy został skonstruowany zgodnie z przesłankami etnicznymi, nadal trwają. Nie ulega jednak wątpliwości, że na przełomie XIX i XX wieku idea niepodległego demokratycznego państwa ukraińskiego, w którym miano zniwelować wszystkie sprzeczności społeczne, zaistniała wśród Rusinów galicyjskich jako pewnego rodzaju idylla, chociaż oddalona w perspektywie czasowej. W celu osiągnięciu tego ideału w niektórych środowiskach czyniono także przygotowania do walki zbrojnej.

Pozostaje pytanie o korelacje zbiorowych tożsamości narodowych oraz indywidualnych wyborów w warunkach galicyjskiej wielokulturowości. Nawet w rodzinach znanych działaczy ruchu ukraińskiego dość często na bieżąco mówiono w języku polskim. Rzeczywiście nie zawsze stanowiło to jakiś problem, a jednak mogło nim zostać. Od końca XIX wieku praktykę ślubów mieszanych włączono w dyskurs

62 A. Świątek, Gente Rutheni, natione Poloni. Z dziejów Rusinów narodowości polskiej w Galicji, Kraków 2014; A.A. Zięba, Gente Rutheni, natione Poloni. Z problematyki ksztaltowania się ukraińskiej świadomości narodowej w Galicji, „Prace Komisji Wschodnioeuropejskiej” 1995, t. 2, s. 61-77; М. Мудрий, Ідея польсько-української унії та „русини польської нації” в етнополітичному дискурсі Галичини 1859-1869 років, „Вісник Львівського університету. Серія історична” 2005, т. $39-40$, s. $83-148$. 
o charakterze narodowym: od czasu do czasu przestrzegano Ukraińców przed poślubieniem Polek i polonizacją rodzin, co miało zakończyć się „grobem szczęścia rodzinnego"63. Za przykład skomplikowanego powiązania losów własnych i problemu wyborów narodowych w Galicji może posłużyć rodzina nauczycielki Ulany Krawczenko. Urodziła się ona w rodzinie niemieckiego urzędnika i córki księdza greckokatolickiego. Została nauczycielką ludową ,,z wyboru”, pragnęła bowiem pracować dla dzieci ukraińskich. Pisała też utwory literackie, zauważone przez Iwana Frankę. Poślubiła dyrektora szkoły, w której pracowała, Jana Niemiętowskiego, Polaka i zwolennika polskiej demokracji narodowej. Mieli troje dzieci: dwie córki ochrzczono w obrządku greckim, syna - w łacińskim. Jedna córka wyszła za mąż za lekarza, który był Niemcem, i wróciła w ten sposób do tożsamości niemieckiej dziadka, inna pozostała przy matce i tożsamości ukraińskiej, natomiast syn zginął jako żołnierz polski w walkach polsko-ukraińskich. Widzimy zatem, że ,wielkie” procesy dziejowe, do jakich niewątpliwie należało kształtowanie nowoczesnej tożsamości narodowej, przechodziły przez losy „małych” ludzi, niejednokrotnie komplikując ich życie rodzinne i życiowe plany.

\section{BIBLIOGRAFIA}

\section{I. Źródła}

\section{1. Źródła archiwalne}

Львівська національна наукова бібліотека України ім. В. Стефаника, відділ рукописів: ф. 41: Грушкевичі, спр. 123 / п. 24 / 1-8, арк. 147 зв.148 (Щоденник Т. Грушкевича, запис від 20 січня 1909 р.).

Центральний державний історичний архів України, м. Львів:

ф. 372: Охримович Володимир, оп. 1, спр. 14, арк. 8 (обіжник Народного комітету УНДП від 28 лютого 1903 р.).

\section{2. Źródła drukowane}

Отзывъ [w:] Съъздъ мужей довърія русско-народной партіи и ея организачія, Львовъ 1900.

Прибудь розум - щастя буде! Розмова Русина з Турчанського повіту з послом Константином Телішевським, Львів 1891.

Уставъ Галицко-рускаго благотворительнаго общества въ С.-Петербургь, С.-Петербургъ 1913.

63 Львівська національна наукова бібліотека України ім. В. Стефаника, відділ рукописів, ф. 41: Грушкевичі, спр. 123 / п. 24 / 1-8, арк. 147 зв. 148 (Щоденник Т. Грушкевича, запис від 20 січня 1909 p.). Dokładniej o konotacjach narodowych ślubów mieszanych w: I. Черч ов ич, „Не дружсися русин з полькою - буде суперечка". До історії зміманих шлюбів у Галичині другої половини XIX початку ХХ століття, „Історичні та культурологічні студії” 2014-2015, т. 6-7, s. 81-88. 


\section{Wydawnictwa źródłowe}

Podoliński B., Stowo przestrogi [1848], вид. Ф. Стеблій, „Записки Наукового товариства імені Шевченка" (Львів) 1994, т. 228: Праці Історично-філософської секиї, s. 444 462.

Головна Руська Рада. 1848-1851. Протоколи засідань $i$ книга кореспонденції, ред. О. Турій, упоряд. У. Кришталович, І. Сварник, Львів 2002.

За віру, нарід і права. Руські Ради Надсяння 1848-1850 рр., вступ та упоряд. В. Пилипов ич, Перемишль 2005.

\section{Wspomnienia, pamiętniki, korespondencja}

[Барвінський В.] Василь Барвінок, Скошений и̧віт (виїмок з галицььких образків), вступ Б. Лепкий, Київ-Ляйпціг 1910.

Барвінський О., Спомини з мого життя, т. 1-2, упоряд. А. Шацька, О. Федорук, ред. Л. Винар, І. Гирич, Нью-Йорк-Київ 2004.

Вахнянин А., Спомини з житя (Посмертне виданя), зладив К. Студинський, Львів 1908.

Дорошенко Д., Мої спомини про недавнє минуле (1914-1920рр.), Київ 2007.

Олесницький Є., Сторінки з мого життя, упор. М. Мудрий, Б. Савчик, авт. вступ статті О. Аркуша, Львів 2011.

Переписка Михайла Драгоманова з Теофілем Окуневським (1883, 1885-1891, 1893 1895), Львів 1905.

\section{Dzieła z epoki}

Бачинський Ю., Україна irredenta, передм. І. Бегей, Київ 2003.

Грушевський М., Галичина і Україна [w:] М. Грушевський, Твори у 50 m., т. 1, Львів 2002, s. 376-382.

Гумецкий И., Значеніе русскаго Прикарпатья для Россіи. Прикарпатье, будущее второе Приамурье для Россіи въ предстоящей ей борбь съ вьроломною Западною Европою, С.-Петербургъ 1904.

Дідицкій Б., В одинъ часъ научиться малорусину по велико-русски, Львів 1866.

Мончаловскій О., Святая Русь, Львів 1903.

\section{Prasa}

„Dziennik Narodowy” (Lwów) 1848.

„Батьківщина” (Львів) 1888.

„Діло” (Львів) 1885, 1900, 1902.

„Зоря Галицка” (Львів) 1848.

„Галичанинъ” (Львів) 1907.

„Слово” (Львів) 1861, 1866.

\section{Opracowania}

Chlebowczyk J., O prawie do bytu małych i młodych narodów. Kwestia narodowościowa i procesy narodotwórcze we wschodniej Europie Środkowej w dobie kapitalizmu (od schytku XVIII do poczatków XX w.), Warszawa-Kraków 1983. 
Himka J.-P., The Construction of Nationality in Galician Rus'. Icarian Flights in Almost All Directions [w:] Intellectuals and the Articulation of the Nation, eds. R.G. Suny, M.D. Kennedy, Ann Arbor (Mich.) 1999, s. 109-164.

Himka J.-P., Religion and Nationality in Western Ukraine. The Greek Catholic Church and the Ruthenian National Movement in Galicia, 1867-1900, Montreal-Kingston-LondonIthaca 1999.

Maciak D., Próba porozumienia polsko-ukraińskiego w Galicji w latach 1888-1895, Warszawa 2006.

Magocsi P.R., A History of Ukraine, Toronto 1996.

Magocsi P.R., The Kachkovs'kyi Society and the National Revival in Nineteenth-Century East Galicia, „Harvard Ukrainian Studies” (Cambridge, Mass.) 1991, vol. 15, nr 1-2, S. $48-85$.

Moklak J., W walce o tożsamość Ukrainców. Zagadnienie języka wykładowego w szkołach ludowych i średnich w pracach galicyjskiego Sejmu Krajowego 1866-1892, Kraków 2004.

Osadczy W., Święta Ruś. Rozwój i oddziaływanie idei prawosławia w Galicji, Lublin 2007.

Subtelny O., Ukraine. A History, Toronto 1988.

Świątek A., Gente Rutheni, Natione Poloni. Z dziejów Rusinów narodowości polskiej w Galicji, Kraków 2014.

Tomczyk R., Galicyjska Rusko-Ukraińska Partia Radykalna w latach 1890-1914, Szczecin 2007.

Wójtowicz-Huber B., „, Ojcowie narodu”. Duchowieństwo grecko-katolickie w ruchu narodowym Rusinów galicyjskich (1867-1918), Warszawa 2008.

Zięba A.A., Gente Rutheni, natione Poloni. Z problematyki ksztattowania się ukraińskiej świadomości narodowej w Galicji, „Prace Komisji Wschodnioeuropejskiej” 1995, t. 2, s. $61-77$.

Аркуша О., Кондратюк К., Мудрий М., Сухий О., Час народів. Iсторія України ХІХ століття. Навч. посібн., ред. М. М. Мудрий, Львів 2016.

Аркуша О., Мудрий М., Русофільство в Галичині в середині XIX-на початку XX cm. Генеза, етапи розвитку, світогляд, „Вісник Львівського університету. Серія історична" 1999, вип. 34, s. 231-268.

Бахтурина А., Политика Российской империи в Восточной Галищии в годы Первой мировой войны, Москва 2000.

Вендланд А.В., Русофіли Галичини. Украйнські консерватори між Австрією та Росією, 1848-1915, Львів 2015.

Грицак Я., Нарис історії України. формування модерної української нації XIX-XX cm., Київ 2000.

Грицак Я., Пророк у своїй вітчизні. Франко та його спільнота (1856-1886), Київ 2006.

Заярнюк А., Ідіоми емансипації. „Визвольні” проєкти і галииьке село в середині ХІХ століття, Київ 2007.

Киричук О., Львівський Ставропігійський інститут у громадському житті Галичини другої половини XIX-початку XX ст., Львів 2001.

Колб Н., ,, 3 Богом за Церкву і Вітчизну”. Греко-католицьке парафіяльне духовенство в Галичині у 90-х роках ХІХ століття, Жовква 2015.

Кудлач-Мельник В. І., Політичне товариство „Руська Рада” (1870-1914 рр.), автореф. дис. канд. іст. наук, Івано-Франківськ 2008. 
Куций І., Украӥнська науково-історична думка Галичини (1830-1894). Рецепџія наџіональної історії, Тернопіль 2006.

Мозер М., „Язичіє” - псевдотермін в украӥнському мовознавстві [w:] Причинки до історії української мови, ред. С. Вакуленко, Вінниця 2011, s. 641-666.

Мудрий М., Поняття „наша земля” / „, наш край” в украйнському русі Галичини ХІХ - початку XX століття [w:] Шляхами історії. Науковий збірник історичного факультету ЛНУ ім. І. Франка. На пошану проф. К. Кондратюка, Львів 2004, s. 160 177.

Мудрий М., Ідея польсько-української унії та „русини польської нації” в етнополітичному дискурсі Галичини 1859-1869 років, „Вісник Львівського університету. Серія історична" 2005, т. 39-40, s. 83-148.

Нахлік Є., Пантелеймон Куліш. Особистість, письменник, мислитель, т. 1: Життя Пантелеймона Куліша, Київ 2007.

Орлевич I., Ставропігійський інститут у Львові (кінецьь XVIII - 60-рp. XIX cm.), Львів 2001.

Пахолків С., Украӥнська інтелітенція у Габсбурзькій Галичині. Освічена верства і емансипація нації, Львів 2014.

Плохій С., Великий переділ. Незвичайна історія Михайла Грушевського, Київ 2011.

Поповкин А., Славянские благотворительные общества в Москве и Санкт-Петербурге (1858-1921 г2.), диссертация канд. ист. наук, Воронеж 2013.

Райківський I., Ідея української національної єдності в громадському житті Галичини ХІХ століття, Івано-Франківськ 2012.

Расевич В., Українська національно-демократична партія (1899-1918 рр.), автореф. канд. дис., Львів 1996.

Сарбей В. Г., Наџіональне відродження України, Київ 1999.

Седляр О., „Галицько-руська матиия”. Завдання, організація, члени товариства, „Україна. Культурна спадщина, національна свідомість, державність” 2012, t. 21, s. 668-692.

Середа О., Громади ранніх народовиів у Східній Галичині (60-і роки ХІХ століття), „Україна. Культурна спадщина, національна свідомість, державність” 2001, т. 9, s. 378-392.

Сіромська Г., Народний Дім у Львові. Від старорусинства до русофільства (середина $X I X$ - початок XX cm.), Львів 2014.

Скринник М., Наративні практики української ідентичності: доба Романтизму, Львів 2007.

Сух ий О., Від русофільства до москвофільства (російський чинник у громадській думиі та суспільно-політичному житті галицьких україниів у ХІХ столітті), Львів 2003.

Химка І. П., Греко-католиияька ичерква і наџіональне відродження у Галичині 1772 1918, „Ковчег” 1993, № 1, s. 72-107.

Черчович I., „Не дружися русин з полькою - буде суперечка”. До історії змішаних шлюбів у Галичині другої половини XIX - початку XX століття, „Історичні та культурологічні студіï” 2014-2015, т. 6-7, s. 81-88.

Чорновол І., Польсько-українська угода 1890-1894 рр., Львів 2000.

Шлемкевич М., Галичанство, Нью-Йорк-Торонто 1956.

Янишин Б., Українська міська політична еліта в Галичині та народовський рух останньої третини ХІХ сm. Становлення та інституційний розвиток, Київ 2008. 